\title{
ETHNIC DIVERSITY IN TEACHING SOROGAN OF PESANTREN
}

\author{
Ummah Karimah ${ }^{1}$
}

\begin{abstract}
This study aims to describe the teaching of sorogan in the pursuit of books in Islamic boarding schools with ethnic diversity. Ethnic diversity of the kyai (teacher) and the santri (student). This research explains the implementation of sorogan teaching to produce a product in santri. This research is descriptive qualitative research. In collecting data used the interview method and observation. The results of this study are that in the learning process using the Sorogan method there are problems in the adjustment of santri in taking lessons and the cultural language of the pesantren itself as a learning process of the santri in boarding schools (Pesantren).
\end{abstract}

Keywords: Ethnic Diversity, Pesantren, Sorogan.

JOMSIGN: Journal of Multicultural Studies in Guidance and Counseling

Website: http://ejournal.upi.edu/index.php/JOMSIGN

Permalink: http://ejournal.upi.edu/index.php/JOMSIGN/article/view/6314

How to cite (APA): Karimah, U. (2018). Ethnic Diversity in Teaching Sorogan of Pesantren. JOMSIGN: Journal of Multicultural Studies in Guidance and Counseling, 2(2), 92-103

This is an open-access article distributed under the terms of the Creative Commons Attribution 4.0 International License, which permits unrestricted use, distribution, and reproduction in any medium, provided the original work is properly cited.

\section{INTRODUCTION}

Indonesia is a country that has thousands of islands and thousands of tribes and languages, from Sabang to Merauke, which has thousands of regional languages, but in unity, Indonesian has a slogan: Bhineka Tuggal Ika. Although there are different ethnic groups, languages, religions, they are still a unity of the Republic of Indonesia. In Indonesia, there are 1,340 tribes and have 1,211 languages. Likewise, the boarding school Yayasan El-Nur El-Kasysyaf Tambun Bekasi has students who come from outside the tribe where the cottage is located and united in teaching sorogan through the study of the yellow book.

The hope for students is not to deport the books of Fiqh Almu'tabarah which are usually taught in pesantren because of the tradition of our unitary pesantren language, Indonesian is extinct due to the presence of foreign languages. Foreign language is used without minimizing the spirit of students in yellow books. This means that students must combine foreign languages and yellow books and may also speak foreign languages, but without reducing the

\footnotetext{
${ }^{1}$ Institut Agama Islam Shalahuddin Al Ayyubi Tambun Bekasi; umm4h_syarif@yahoo.co.id
} 
culture that is still thick in our culture as Indonesian citizens who exist in the culture of ancestral heritage.

One of the determining factors and influences on social change and development is education. Education is a process that produces the next generation to have a strong character as the recipient of the national leadership baton. One of them is an Islamic boarding school.

One of the Islamic educational institutions and community subculture in Indonesia is Islamic boarding schools. One institution that has a unique and strong uniqueness and strength. Education in Islamic boarding schools teaches students hard times to survive until now. According to Dhofier (1981) the purpose of pesantren education is not to pursue the interests of worldly power, money and grandeur, but to be implanted in God. Therefore, the responsibility as an educational institution, boarding schools have obligations in shaping the character of the students. And study religious knowledge in depth (Zuhriy, 2011: 296)

One typology of pesantren is salafiyah (Zuhriy, 2011: 291) is a type of boarding school that only teaches Islamic religious sciences, or classic books written by previous scholars, the teaching method used is only the bandongan, sorogan, memorization and deliberation methods. The first pesantren model that emerged was the salafiyah or traditional pesantren. These pesantren are usually located in rural areas, so the colors that appear are pure zuhud, simplicity, and sincerity. But along with the development of the times, inevitably pesantren must adapt and adopt new thoughts related to the education system which includes many things such as curriculum, democratic-collective leadership patterns.

Some pesantren (Zuhriy, 2011: 289) were originally established only to accommodate local children who intend to study religion and read the yellow book so that the teaching model only uses the method of sorogan and bandongan. One of the characteristics of Islamic boarding school education is the sorogan teaching method which has experienced extraordinary development and the method has never been abandoned by educational practitioners in Islamic boarding schools in modern times. The institution intensively provides education to its students, called santri by the kyai or cleric through several teaching methods that are typical of being in a boarding school environment. However, along with the times, now this activity does not only teach the Qur'an and classic books with bandongan and sorogan, but has been used to teach the 
Madrasa system so that it involves many clerics and religious teachers (Zuhriy, 2011: 289).

Zamakhsyari (2009) did not give a specific understanding of pesantren, he only gave criteria for a pesantren which he considered to be the five basic elements of the pondok pesantren tradition including mosques, santri, teaching classical Islamic books, and kyai.

The vision of development that seeks to save and improve life needs to develop the pesantren curriculum based on educational innovation and should be adjusted to the current and future systemic and social demands of the community. Learning materials in Islamic boarding schools, one of them through sorogan culture, is a provision for students themselves. In life in society, the role of students is as a successor to the nation who can excel himself and become a strong person, has creativity and expertise in his field.

The subject matter and teaching methods are one aspect of the pesantren education system as a portrait in the pesantren. Where knowledge related to Islam can be obtained at Islamic education institutions, Islamic boarding schools. To increase business what he does must be in principle. That is, the characteristics of pesantren as an Islamic educational institution must remain despite the many problems involved such as health, development and development, economy and environment and culture.

This research is motivated by the low resilience of students in adapting learning in Islamic boarding schools to make students inferior and stressful in participating in lessons. One of the weaknesses of the Sorogan method is the lack of understanding of students in translating books from certain languages. The sorogan method demands patience, diligence, obedience and personal discipline of the students so that they can get bored quickly in studying the book.

The reason for the emergence of problems with students is the internal motivation of students when entering Islamic boarding schools. Adjustment of santri culture to the culture of Islamic boarding schools, in everyday language, activities in boarding and madrasa, the rules of the boarding school and madrasa to the ethics where the boarding school is located. The sorogan teaching method requires the readiness of the santri in studying the book by consulting with the kyai or religious teacher and the basis of a teaching method in the forum (Ministry of Religion, 2001; Nafi, 2007). The sorogan method is the most difficult part of the whole method of traditional Islamic education because this 
system requires patience, craft, obedience, and personal discipline of students (Zamakhsayari, 2015).

Based on the discussion and various studies conducted previously, it can be understood that in the study of the book through the sorogan method there is a cultural value as classical guidance for students. Various studies and theoretically reveal the value of sorogan culture in various educational settings in Islamic boarding schools, however, there has not been much research directed in general education settings. Research on the value of sorogan culture in learning science. This research is the application of the Sorogan-Bandongan integrated lecture model on the nucleophilic substitution reaction mechanism material. This study aims to determine the material that needs to be emphasized in lectures (Rinaningsih, 2014)

This study aims to determine the ethnic diversity in the teaching of sorogan in the El-Nur El-Kasysyaf Tambun Islamic boarding school in Bekasi, more focused on (a) sorogan activities, (b) constraints, (c) views of students and kyai on the value of sorogan culture.

\section{METHOD}

The approach used in this research is a descriptive qualitative approach. Observed behavior is the result of research in the form of descriptive data in the form of written or oral from people. Researchers use qualitative research methods to get natural data following the findings of existing phenomena. As the characteristic of qualitative research is often called the "naturalistic research method" because the research is carried out in natural conditions.

Transcripts, interviews, field notes, and photographic images resulting from qualitative research and processing data that are descriptive. In this study, the authors used descriptive qualitative research. This descriptive research aims to gather actual information in detailed ways that describe the symptoms that exist, identify problems or check the conditions and practices that apply. The descriptive method is used to systematically describe the facts found. Determine what others are doing in dealing with the same problem and learn from their experiences to set plans and decisions in the future.

In this study, researchers observed the subject when at the cottage, and school. In data collection techniques in the form of interviews, we conducted interviews with several parties. Collecting data in this way is an attempt to 
collect information from several parties by asking some questions verbally to be answered verbally as well. Informants are divided into two, namely direct informants and indirect informants. Direct informants are students who follow the teaching of sorogan (call it Farah). Indirect informants are boarding school caretakers, administrators, and close friends of the subject. In data collection techniques in the form of observations, we do it with administrators and teachers in schools. As observation media, we use classrooms, halls, prayer rooms and rooms in Islamic boarding schools.

\section{RESULTS AND DISCUSSION}

Islamic boarding school education is one of the traditional forms of education and the oldest Islamic education system in Indonesia. The existence of pesantren was around five hundred years ago. A place to blend various levels of society into one in it. From the common people to priyayi studying at pesantren. Fellow students communicate with each other and interact with each other. A sense of selfishness or dichotomization due to differences in the degree of each individual is not visible.

There are several definitions of pesantren and many differences of opinion among experts. Pius and Dahlan (in Munjahid, 2011) simply explained the definition of pesantren, that is, a study institution. Islamic boarding school education aims to be the basis of the spread of religious teachings as a moral and mental fortress in the face of technological advances (Soyomukti, 2010). Whereas Machasin (in Munjahid, 2011) explains the understanding of pesantren from a historical point of view, as a place for santri to live where the teacher provides land, then the santri builds itself and the pesantren relies on the word santri. Nuryadin's research results (2014) explain that Islamic boarding schools manage existing diversity as a means of anticipating small and large scale conflicts that are prone to emerge if not managed wisely. Through multicultural education that is implemented early can anticipate the emergence of conflict and provide a wise understanding of the need to accept and manage the reality of diversity.

According to Sukamto in the book, Noor explained that the establishment of boarding schools is usually inseparable from the socio-cultural conditions of the local community, according to oral tradition, it is not uncommon for places of origin of boarding schools to stand differently in small hamlets whose inhabitants are diverse or have not yet performed religious sharia. (Noor: 2009). 
Islamic boarding schools have educational systems that are oriented towards understanding the yellow book (classical) and print cadres of future scholars and are expected to foster and direct the people towards the goodness of capable community leaders. In Islamic boarding schools to build the spiritual side (Sufism) and occupy a major portion in teaching.

In the teaching system in Islamic boarding schools there is a sorogan system and a bandongan system. The individual system in the pesantren teaching system is called the sorogan system which is given in the recitation to students who have mastered the reading of the Qur'an. The bandongan system called the weton system is a system of teaching a group of santri (between 5 to 500 santri) listening to an ustadz who reads, translates, explains and even frequently reviews Islamic books in Arabic.

The sorogan system in this study is the most difficult part of the entire pesantren teaching system, because the sorogan system requires (1) patience, (2) craftsmanship, (3) obedience, and (4) personal discipline of mentor and santri teachers. The sorogan system proved to be very effective as the first stage for a santri who aspires to be pious. This system allows a teacher to supervise, assess, and guide the maximum ability of a santri in mastering Arabic. (Zamakhsyari Dhofier, 2015)

Santri in Islamic boarding schools has learning activities using the sorogan method. According to Mastuhu (in Basuki, 2003) the sorogan method is individual learning where a santri faces the teacher, and mutual interaction occurs between the two. One of the benefits contained in the sorogan method is the essence of life skills education, namely rational thinking skills, including the ability to explore and find information, the ability to process information and make decisions, and the ability to solve problems creatively.

Some research results explain that the Sorogan method is a logical consequence of providing maximum services to the students. Maturity and attention, as well as one's skills, can be produced from the sorogan method. The purpose of the method of encouragement is to encourage students to understand the subject matter that is in the discussion of a yellow book and the purpose of the close relationship between students and religious teachers. Besides, in the method of sorogan the cleric can use it to explore mental turmoil or problems faced by each santri, especially those that have the potential to be disturbed by the absorption of knowledge. Certainly, this method also has advantages and disadvantages. Understanding awareness of cultural diversity in pesantren 
education is one of the main fields of cultivation of multiculturalism. Because education occupies an important position in the social paradigm. Every education in this country is one of them is a boarding school, absolutely must run a diversity-based education. And there is no more dichotomization and racism, culture, religion, and gender. So that the unity and unity of the Pun people can also be built firmly.

Education, as the main means of developing the potential of human resources, must not discriminate against one another. Both students, students, teachers, and lecturers must have an attitude of diversity (plurality), equality (equality), humanity (humanity), justice (justice), and democratic values (democratic values). Some of these aspects are the principles held in educational multiculturalism (Afwadzi,).

Educational diversity theoretically comes from western scientific discourse. However, if explored further, pesantren applies the principles of the theory in their daily educational activities. Some of the educational systems and teaching activities in pesantren are as follows:

First, in the pesantren tradition, there is no dichotomy between the rich and the poor, both students from middle and high-class people live on the same roof. Santri gathers, study, and sleep in the room that has been provided previously. Similarly, all students are treated equally regardless of social status in the teaching-learning process.

Secondly, in pesantren, there is no ethnic and cultural exclusivity. In boarding schools santri who are boarding students do not only come from one region. But sometimes it comes from various geographical regions in Indonesia. All students are treated equally. Santri who comes from the local area and from outside the region, all students together have the opportunity to advance and develop their creativity and knowledge.

Third, in pesantren education - especially pesantren which has the ideology of NU, it teaches the understanding of tasamuh (tolerance), tawasuth (moderate), tawazun (balanced), and i'tidal (perpendicular) such ideas are always echoed for every student expected from here some cadres are moderate, fair, and can accept plurality gracefully.

Fourth, Islamic boarding schools are Islamic educational institutions, teaching tolerance among religious people. Therefore it is not possible to have students from non-Muslim circles. Different beliefs are empirical realities that 
cannot be covered up, but not because they lead to discrediting and hostility towards other religions.

Fifth, the love of the motherland is instilled. Regarding this, in studies in pesantren there is jargon - by not saying the hadith "Hubbu al-Wathan min alIman" (loving the motherland is part of faith). The implication, he is not considered a faith if someone does not love his homeland. So implicitly, pesantren voiced to always accept the condition of our nation and state as it is, which is indeed made up of various ethnicities, cultures, and religions.

One method used in the study of the yellow book is the sorogan method. Before discussing activities in sorogan, the understanding of the sorogan method consists of two words, namely method and sorogan. The word method comes from two words namely meta and hodod have the meaning "way or way" (Arifin, 2003: 65). The word method has the meaning "a path traveled to achieve a goal". The method is one component of the education process, a tool to achieve goals supported by learning aids, and is a roundness in the education system (Zein, 1995: 11). From the explanation, the authors conclude that the method is a process in achieving goals. Likewise in the sense of the sorogan method, a process of achieving santri to understand the learning material of the yellow book. In learning a teacher must be able to choose the method properly and appropriately so that it has results that are following the aims of education and teaching. One of them is the sorogan method is considered as a complicated and difficult method in the world of education and traditional learning. The success of the sorogan method is very much determined by the students' obedience to the kyai and his cleric.

Islamic boarding school is an education that is held in a formal form. In general, Islamic boarding schools organize education based on religious values. The development of the times requires this institution to develop general sciences that must be studied by students without ignoring the knowledge of their religion. (Sopidi, 2014: 291)

Some of the literature that has been presented previously ultimately put this study to find its urgency. In addition to the inadequacy of similar research on themes raised by researchers, this study seeks to contribute to strengthening the value of sorogan culture as classical guidance in Islamic boarding schools.

In Sopidi's research (2014) explained that one of the development of character education in As-Sakinah Pesantren is cultural capital. The cultural capital in question is in the form of learning using the system (method) sorogan 
and bandongan. Learning systems such as sorogan and bandongan are the hallmarks of the classical pesantren/salaf. If in the sorogan learning method the kyai explains the contents of the book in detail and is followed by a smaller number of students.

The development of pesantren is also in the material being taught. Since the growth of pesantren the teaching of classical Islamic books were given as an effort to continue the main purpose of the pesantren, namely to educate prospective scholars (Djuhan, 2006: 4). An integral part of the values and understandings of boarding schools that are interrelated, boarding schools as madrassas with a system of huts or boarding houses with classical books which is the main goal of the boarding school.

Literature and clerics are classical Islamic books (yellow book) and are not separated from the clerics in the Islamic boarding school for the existence of these classical Islamic books. Modification of the values of teachings and clerics is a personification of these values contained in classical Islamic scriptures. The cleric is a role model for the people not only in the boarding school santri but also in the broader sense of the Islamic community. The typical method taught in classical Islamic books is the main goal in pesantren which aims to produce students to master knowledge about Islam. Djuhan (2006: 5) The method used in our teaching - the classic Islamic books in pesantren, namely sorogan - one-on-one facing the kyai with a particular book, still the early santri and the book is small, the kyai reads several lines of books with the meanings commonly used in pesantren, usually adjusted to the language where the boarding school is located. After reading, the santris repeat the teachings of the kyai after they are considered quite advanced, and so on.

The method applied in sorogan is santri facing kyai or ustadza individually to deposit memorization or study the book directly so that the ability of santri can be controlled by the cleric or his clerics. The ability of a santri to learn the yellow book maximally can be monitored, assessed and guided by a cleric or cleric.

The predecessors of the teaching methods in the pesantren were used, such as the sorogan and bandongan methods according to the existing schedule or weton. Sorogan cultural value is also a method of teaching the kyai (ustadz) to transfer knowledge from the book being studied. The book under review is material that is adapted to the needs of students and includes a form of classical 
guidance of students in addition to knowledge and prepares students to be a formidable and independent future generation.

The order of methods in the series of teaching systems is after the material delivered by the teacher or teacher in learning activities. The results of education and teaching are obtained from the great role of a teacher in choosing the right teaching method and using it according to the needs of students. Some experts put forward the notion of sorogan is an individual learning method between the kyai - santri, by dictating (imitating) the material of the book being taught. (Nata; 2001: 108, Mastuhu; 1999, Arif; 2002: 150, Hasbullah; 1995: 145)

The superiority of the pesantren tradition in the sorogan education system, according to Dr. Qodri Azizy, is located in its multidimensional role in community life, both in the fields of ideology, social, economic, cultural, political and others. One community that can form a distinctive culture is pesantren. (Zuhry, 2011).

Relevant research from the results of research by Sugiati (2016) shows that through the method of sorogan the relationship between religious teacher or Kyai with students can be closer. Teachers can recognize their cognitive and personal abilities individually one by one with different cultural backgrounds. The method in this study uses qualitative research methods through observations and interviews about cross-culture in the sorogan method of book learning.

The conclusion is that in Islamic boarding schools in reality in the learning process using the sorogan method there are still problems in adjusting students to attend lessons and the cultural language of Islamic boarding schools itself as a cross-cultural process in Islamic boarding schools. The solutions provided for the achievement of the objectives of Islamic boarding school in terms of students can learn and understand and apply the lessons received, then there is a self-understanding in the cleric or Kyai and students of the cultural language of the boarding school itself.

\section{CONCLUSION}

The basis of the author's opinion that in essence pesantren has actualized the principles of diversity in the education system. Whether we realize it or not, pesantren which are included in people's education have taught diversity, equality, humanity, justice, and democratic values. And efforts to unite the diversity of santri tribes in Islamic boarding schools. 


\section{REFERENCES}

Ahmad, M. A. (2012). Liberalisasi Islam di pesantren (Refleksi pemikiran santri). Kediri: Pustaka Sidogiri.

Basuki. (2003). Pesantren dan pendidikan kecakapan hidup (Life skills). Jurnal Cendikia, 5(2), 292-310.

Dhofier, Z. (2015). Tradisi pesantren: Studi pandangan hidup kyai dan visinya mengenai masa depan Indonesia. Jakarta: LP3ES.

Djuhan, W. M. (2006). Urgensi materi sejarah dalam pengembangan kurikulum pesantren. Jurnal Kependidikan dan Kemasyarakatan, Cendekia, 4(2), $1-12$.

Munjahid. (2011). Sekularisasi pesantren. Jurnal Cendekia, 9(1), 15-26.

Noor, A. S. (2009). Orientasi pengembangan pendidikan pesantren tradisional. Jakarta: Prenada Media Group.

Nuryadin. (2014). Pendidikan multikultural di pondok pesantren karya pembangunan puruk cahu kabupaten Murung Raya. Tesis: Program Pascasarjana UIN Sunan Kalijaga.

Rinaningsih. (2014). Implementasi model perkuliahan terpadu soroganbandongan untuk menentukan pemahaman mahasiswa dalam mempelajari mekanisme reaksi. Jurnal Pengajaran MIPA, 19(2), 266274.

Sopidi, S. (2014). Integrasi modal sosial dan budaya dalam pengembangan nilai-nilai pendidikan karakter di pondok pesantren modern as-sakinah sliyeg indramayu. Holistik, 15(2), 287-308.

Soyomukti. (2010). Teori-teori pendidikan. Yogyakarta: Ar-ruz Media.

Sugiati. (2016). Implementasi metode sorogan pada pembelajaran tahsin dan tahfidz pondok pesantren. QATHRUNÂ, 3(1), 135-160.

Tamam, B. (2015). Pesantren nalar dan tradisi (Geliat santri menghadapi ISIS, terorisme, dan transnasionalisme Islam. Yogyakarta: Pustaka Pelajar. 
Ethnic Diversity in Teaching Sorogan of Pesantren

Zuhriy, M. S. (2011). Budaya pesantren dan pendidikan karakter pada pondok pesantren salaf. Walisongo: Jurnal Penelitian Sosial Keagamaan, 19(2), 287-310. 